University of Nebraska - Lincoln

DigitalCommons@University of Nebraska - Lincoln

Agronomy \& Horticulture -- Faculty Publications

Agronomy and Horticulture Department

2006

\title{
Simulated insect defoliation and duration of weed interference affected soybean growth
}

Travis C. Gustafson

University of Nebraska-Lincoln, tgustafson2@unl.edu

Stevan Z. Knezevic

University of Nebraska-Lincoln, sknezevic2@unl.edu

Thomas E. Hunt

Haskell Agricultural Laboratory, University of Nebraska, thunt2@unl.edu

John L. Lindquist

University of Nebraska-Lincoln, jlindquist1@unl.edu

Follow this and additional works at: https://digitalcommons.unl.edu/agronomyfacpub

Part of the Plant Sciences Commons

Gustafson, Travis C.; Knezevic, Stevan Z.; Hunt, Thomas E.; and Lindquist, John L., "Simulated insect defoliation and duration of weed interference affected soybean growth" (2006). Agronomy \& Horticulture -- Faculty Publications. 378.

https://digitalcommons.unl.edu/agronomyfacpub/378

This Article is brought to you for free and open access by the Agronomy and Horticulture Department at DigitalCommons@University of Nebraska - Lincoln. It has been accepted for inclusion in Agronomy \& Horticulture -Faculty Publications by an authorized administrator of DigitalCommons@University of Nebraska - Lincoln. 


\section{Simulated insect defoliation and duration of weed interference affected soybean growth}

Travis C. Gustafson

Department of Plant Pathology, University of Nebraska, Lincoln, NE 68583

Stevan Z. Knezevic

Corresponding author. Haskell Agricultural

Laboratory, University of Nebraska, 57905866

Road, Concord, NE 68728-2828;

sknezevic2@unl.edu

Thomas E. Hunt

Haskell Agricultural Laboratory, University of Nebraska, 57905866 Road, Concord, NE 68728-2828

John L. Lindquist

Department of Agronomy and Horticulture, University of Nebraska, Lincoln, NE 68583

\begin{abstract}
An improved understanding of crop stress from multiple pests is needed for better implementation of integrated pest management (IPM) strategies. Field studies were conducted in 2003 and 2004 at two locations in eastern Nebraska to describe the effects of simulated early-season insect defoliation of soybean and duration of weed interference on soybean growth. Three levels of simulated defoliation (undefoliated, 30 , and 60\%) and seven durations of weed interference (weedy and weed free; weed removal at V2, V4, V6, R3, and R5) were evaluated in a split-plot design. Defoliation significantly reduced soybean leaf-area index (LAI), total dry matter (TDM), and crop height in season-long weedy treatments only. Biomass partitioning during vegetative and reproductive growth was affected by both defoliation and weed interference. Increase in soybean relative growth rate (RGR) and biomass production soon after defoliation occurred (e.g., V5 stage) indicated potential defense mechanism by which soybean is able to adjust its physiology in response to the loss of leaf area. Weed interference combined with defoliation caused the greatest yield losses up to $97 \%$. Results from this study indicate the need for monitoring early-season insect density and weed growth to determine if simultaneous control of both pests may be needed.
\end{abstract}

Nomenclature: Soybean, Glycine max (L.) Merr.

Key words: Critical time for weed removal, integrated pest management, growth analysis, multiple pests, pest complex.
Early season defoliation of soybean by insects is an increasing problem in the Midwest due to earlier crop planting and expanding soybean acreage (Anonymous 2004). Of primary concern is the bean leaf beetle (Certoma trifurcata Förster), which overwinters in the crop residue and can start feeding primarily on soybean within $3 \mathrm{~d}$ after crop emergence (Smelser and Pedigo 1991). Early-emerging soybeans are more susceptible to injury, because the bean leaf beetle preferentially feeds on soybean (Hunt et al. 1994). Even though early-season defoliation is easily noticed, it is typically not considered economically significant until the insect density plant ${ }^{-1}$ reaches the threshold level (Hammond 1989; Hunt et al. 1994, 1995; Weber and Caldwell 1966). Single pest thresholds, however, do not account for the effects of other potential pests, including weeds.

Weeds are the most common pests in the soybean agroecosystem, and appropriate timing of their control is critical for protection of crop yields (Knezevic et al. 2002). One useful strategy in determining the timing of POST weed control is to utilize the concept of critical period for weed control (CPWC) (Knezevic et al. 2002). The CPWC consists of two components. The first is the critical time for weed removal (CTWR), which determines the point in the growing season when weeds must be removed to prevent unacceptable yield losses, and the second is the critical weedfree period, which determines the time in crop growth when late-emerging weeds will no longer cause yield loss (Knezevic et al. 2002). It is also important to know how production factors influence the CPWC. Evans et al. (2003) reported that the increase in nitrogen level reduced the length of CPWC in corn (Zea mays L.), and narrow row spacing delayed the CTWR in soybean (Knezevic et al. 2003a, 2003b).
Varying nitrogen levels in corn and row spacing in soybean also altered crop growth and development (Evans et al. 2003, Knezevic et al. 2003b).

No studies have described soybean growth as influenced by the joint effects of early-season insect defoliation and weed interference, which can be helpful for enhancing IPM strategies in soybean. For example, a better understanding of the interactions between insect defoliation and weed interference may help improve insect and weed management strategies. Therefore, the objective of this study was to describe the effects of simulated insect defoliation and varying durations of weed interference on soybean growth.

\section{Materials and Methods}

\section{Location Description}

Field studies were conducted in 2003 and 2004 at two locations in eastern Nebraska (Lincoln and Concord). A naturally occurring community of weed species was utilized, and locations were selected based on historical presence of weeds common to eastern Nebraska. Fields were cultivated prior to planting to ensure uniform weed emergence within a few days of soybean emergence, and to prepare the seedbed for planting. Previous crops included grain sorghum (Sorghum bicolor) at Lincoln for both years and corn for both years at Concord. Soybean was planted in 19-cm-wide rows on 29 May 2003 and 5 June 2003 in Lincoln and Concord, respectively, and 2 June 2004 and 28 May 2004 in Lincoln and Concord, respectively. Asgrow 'AG2703' and Agripro '2502' were the two glyphosate-tolerant indeterminate soybean varieties used in Lincoln and Concord, respectively, each year. In 2003, a population of 65 and 29 soybean $\mathrm{m}^{-2}$ 
was established at Lincoln and Concord, respectively, and in 2004, 44 and 34 soybean $\mathrm{m}^{-2}$ were at Lincoln and Concord, respectively. Soybean emergence occurred on 9 June 2003 and 8 June 2004 in Lincoln and 16 June 2003 and 7 June 2004 in Concord. Weed emergence coincided with soybean emergence in all location-years, except Lincoln in 2004 , when weed emergence occurred $\sim 2 \mathrm{~d}$ after soybean emergence.

\section{Experimental Design}

A two-factor split-plot design was utilized with the main plot of simulated leaf defoliation at three levels (undefoliated, 30, and 60\%). When soybeans are defoliated at approximately $60 \%$, insecticide application is typically warranted (Hunt et al. 1994, 1995). Thirty percent defoliation was selected in order to see how lower defoliation rates affect weed management. Duration of weed interference was the subplot factor. Seven durations of weed interference (weed removal at V2, V4, V6, R3, and R5; season long weed-free, and weedy) were imposed on each main plot.

Each subplot was an experimental unit and was $4.6 \mathrm{~m}$ wide (consisting of 24 rows spaced $19 \mathrm{~cm}$ apart) and $18 \mathrm{~m}$ long. Defoliation and destructive sampling was done within the center eight rows of each experimental unit with the remaining rows maintained as buffer to minimize any edge effects. Two meters at the end of each plot were left undisturbed.

\section{Field Procedures}

\section{Sequential Defoliation}

Many defoliation studies utilize single-day defoliation techniques to simulate insect injury (Hammond 1989; Talekar and Lee 1988; Weber and Caldwell 1966; Weber 1955). Fewer studies examined defoliation that occurred over several crop growth stages (e.g., from VE to V4 stage) (Fehr and Caviness 1977). Hunt et al. (1994) examined differences between single-day and sequential defoliation methods and found that sequential defoliation with manual leaflet removal better simulates the effects of early-season insect injury.

In our study, three defoliation levels of 0,30 , and $60 \%$ were conducted sequentially over a period of $7 \mathrm{~d}$ starting at VC when the unifoliate leaves unfolded. One leaflet plant ${ }^{-1}$ was clipped daily by hand from plots with $60 \%$ defoliation and one leaflet plant ${ }^{-1}$ was removed every $2 \mathrm{~d}$ in plots with $30 \%$ defoliation. Defoliation was initiated on 17 June 2003 and 22 June 2004 and terminated on 25 June 2003 and 28 June 2004 at Lincoln. At Concord, it was initiated on 27 June 2003 and 21 June 2004 and terminated on 2 July 2003 and 28 June 2004.

Immediately after the final day of defoliation, the first destructive harvest was conducted to determine the actual percentage of defoliation and the mean leaf area plant ${ }^{-1}$ in all three defoliation levels. Then the leaf area plant $^{-1}$ from each defoliated split plot was compared to the undefoliated plots to calculate a percentage of defoliated leaf area.

\section{Weed Removal}

Weeds were removed utilizing glyphosate and hand weeding as needed. A backpack sprayer charged with $\mathrm{CO}_{2}$ was utilized to make applications of a commercial formulation of glyphosate ${ }^{1}$ at the manufacturer's recommended label rate based on weed height throughout the season with a water volume of $187 \mathrm{~L} \mathrm{ha}^{-1}$ to ensure adequate coverage of the herbicide. Subsequent applications of glyphosate were performed in plots exhibiting second flushes of weeds on an as-needed basis to maintain a weed-free environment.

\section{Plot Maintenance}

All insect pest populations were monitored and controlled in order to eliminate confounding effects from natural communities of insects. A common bean leaf beetle management practice is delayed planting of soybeans. Therefore, soybeans in this study were planted relatively late in order to reduce natural infestations of bean leaf beetle. Late-season infestations of soybean aphids (Aphis glycines M.) were also monitored and controlled if necessary. Bean leaf beetles can transmit the bean pod mottle virus. This study could not determine the effects of disease transmittance because simulated defoliation was used and actual bean leaf beetle feeding was minimized.

\section{Crop and Weed Measurements}

Destructive harvests of soybean and weed biomass were taken at V3, V5, V7, R3, and R5 soybean growth stages. One-meter lengths of the center four defoliated rows were harvested at each sampling time. Sampled areas were separated by $1 \mathrm{~m}$ of undisturbed soybean to minimize any border effects. Soybeans were clipped at the soil surface, leaves were removed from stems (petioles were left attached to stems), and leaf area was determined with the use of an area meter. ${ }^{2}$ At R3 and R5 samples, pods were also removed from stems, counted, dried, and weighed separately from the other plant components. Soybean data recorded at each harvest included growth stage; number of plants; leaf area; dry matter of stem, leaf, and pod (when present); number of pods; number of branches plant $^{-1}$; number of plants that produced branches; and soybean canopy height prior to clipping. Crop leaf, stem, and pod components were bagged separately and dried at $70 \mathrm{C}$ to constant weight. Weeds from the harvest area were also clipped at the soil surface and placed in bags, dried, and weighed to determine total aboveground weed biomass. Weed canopy height prior to clipping was also measured, and weed density was recorded at the V6 crop growth stage only.

\section{Growth Curves and Statistical Analyses}

The effect of years, locations, defoliation levels, weed removal times (RT), and their interactions on the various growth parameters were tested with the use of ANOVA (PROC MIXED in SAS3 version 8.0, Littell et al. 1996). Fixed effects were replication, defoliation, duration of weed interference, year, and location and their relevant interactions. Random effects were replication by defoliation interactions. All data were separated by location and year due to significant location-by-year interactions $(P<0.05)$, unless otherwise noted. If the defoliation level by RT interaction was not significant, further analysis was conducted with main effect treatment least-squares means. Linear or nonlinear least-squares regression models were used to quantify 
TABle 1. Temperature (C) and precipitation $(\mathrm{mm})$ at Lincoln and Concord in eastern Nebraska for 2003 and 2004.

\begin{tabular}{lrrrrr}
\hline & \multicolumn{2}{c}{ Lincoln } & & \multicolumn{2}{c}{ Concord } \\
\cline { 2 - 3 } \cline { 5 - 6 } & 2003 & 2004 & & 2003 & 2004 \\
\hline Temperature & & & & \\
$\quad$ May & 15.6 & 18.1 & & 14.2 & 15.0 \\
June & 20.5 & 20.6 & & 20.2 & 18.7 \\
July & 25.9 & 22.9 & & 23.1 & 21.3 \\
August & 25.1 & 21.6 & & 23.0 & 19.4 \\
September & 20.2 & 22.1 & & 19.1 & 20.3 \\
October & 13.1 & 13.1 & & 11.3 & 10.4 \\
Precipitation & & & & \\
$\quad$ May & 68.0 & 118.5 & & 85.5 & 115.5 \\
June & 167.0 & 71.0 & & 44.0 & 48.5 \\
July & 25.8 & 131.0 & & 72.5 & 59.0 \\
August & 32.8 & 44.5 & & 16.5 & 15.0 \\
September & 91.5 & 12.8 & & 38.8 & 14.5 \\
October & 24.8 & 10.0 & & 18.3 & 17.3 \\
Total & 409.9 & 387.8 & & 275.6 & 269.8 \\
\hline
\end{tabular}

treatment effects on crop growth parameters. When appropriate, least-squares treatment means were compared with the use of $t$ tests at each plant sampling time.

Data analysis for various growth parameters was performed with the use of regression models, as in the growth analysis procedures outlined by Hunt (1982). All data depicting growth throughout the growing season or responses to duration of weed interference are plotted with the use of growing degree days (GDD) as the explanatory variable. GDD was calculated from soybean emergence with the use of $10 \mathrm{C}$ as the base temperature and $30 \mathrm{C}$ as maximum temperature. GDD can also be related to the crop growth stage, which is easily understood by producers, consultants, and other practitioners (Knezevic et al. 2002, 2003a; Martin et al. 2001).

Soybean height over time was described by the Gompertz model (Equation 1):

$$
H=H_{\max } \exp [-q \exp (-c T)]
$$

where $H$ is soybean height in centimeters, $H_{\max }$ is maximum attainable height, $T$ is time after crop emergence measured in GDD. The coefficients $q$ and $c$ are constants. Soybean biomass and LAI at R3 were related to duration of weed interference for each defoliation level with the use of:

$$
Y=[1 /\{(\exp [k(T-d)]+f\}+[(f-1) / f]] a
$$

where $Y$ is either LAI or total biomass plant ${ }^{-1}, d$ is the point of inflection in GDD, $a$ is the weed-free treatment mean, $k$ and $f$ are constants, and $T$ is duration of weed interference in GDD after emergence. Parameters from Equations 1 and 2 were tested for differences between defoliation levels ( $\mathrm{P}<$ 0.05 ) with the use of PROC NLMIXED in SAS.

RGR of biomass was calculated for each split plot with the use of the following equation:

$$
\mathrm{RGR}=a b g \exp [-g T-b \exp (-g T)]
$$

where $T$ is time after crop emergence measured in GDD and $a, b$, and $g$ are constants. Equation 3 is the first derivative of Equation 1 with respect to total biomass instead of plant height.
TABle 2. Weed species composition and density at Lincoln and Concord over 2 yr. Listed weed species represented above $95 \%$ of total weed density.

\begin{tabular}{lclc}
\hline Location & Year & \multicolumn{1}{c}{ Species } & Density \\
\hline \multirow{3}{*}{ Lincoln } & \multirow{2}{*}{2003} & Amaranthus spp. & plants $\mathrm{m}^{-2}$ \\
& \multirow{2}{*}{2004} & 70 \\
& & Abutilon theophrasti & 33 \\
& Helianthus annuus & 31 \\
& & Amaranthus spp. & 8 \\
& & Abutilon theophrasti & 7 \\
& Helianthus annuus & 2 \\
& & Chenopodium album & 2 \\
Concord & \multirow{2}{*}{2003} & Setaria spp. & 2 \\
& & Setaria spp. & 114 \\
& & Abutilon theophrasti & 41 \\
& & Amaranthus spp. & 29 \\
& \multirow{2}{*}{2004} & Setaria spp. & 21 \\
& & Abutilon theophrasti & 17 \\
& & Amaranthus spp. & 13 \\
& & Solanum ptycanthum & 5 \\
\hline
\end{tabular}

Biomass partitioning coefficients were calculated with the use of Equation 4 (Hunt 1990):

$$
\mathrm{PC}_{0}=\Delta W_{\text {component }} / \Delta W_{\text {total }}
$$

where $\mathrm{PC}_{0}$ is the partitioning coefficient (PC) of leaf, stem, or reproductive components, $\Delta W_{\text {component }}$ represents the change in dry matter of a component between two sampling dates, and $\Delta W_{\text {total }}$ is the change in total aboveground dry matter between the two sampling dates. PCs were calculated for each plant component (leaf, stem, or reproductive) within each experimental unit. Treatment means were compared with the use of a $t$ test $(\mathrm{P}<0.10)$.

\section{Results and Discussion}

In 2003, Lincoln received $410 \mathrm{~mm}$ of rainfall between the months of May and October; $235 \mathrm{~mm}$ fell prior to the initiation of defoliation. In 2004, Lincoln received $388 \mathrm{~mm}$ with $190 \mathrm{~mm}$ precipitation before defoliation. In 2003 and 2004, Concord received $175 \mathrm{~mm}$ and $137 \mathrm{~mm}$ rainfall, respectively. Less than half of the seasonal rainfall occurred before defoliation in 2003, and more than half of the precipitation occurred before defoliation in 2004 at Concord (Table 1). Weeds present at each location included velvetleaf (Abutilon theophrasti M.), common sunflower (Helianthus annuus L.), waterhemp species (Amaranthus spp.), and foxtail species (Setaria spp.) (Table 2). Three different defoliation levels were achieved in each year by location. However, due to the nature of defoliation studies, the exact targeted defoliation levels could not always be met. Actual defoliations ranged from 24 to $45 \%$ for the $30 \%$ defoliation level and 51 to $70 \%$ for the $60 \%$ defoliation level (Table 3). There was a location-by-year interaction for most variables tested; thus the selected variables were presented by year and location (Figures 1 to 4, Tables 4 to 7).

\section{Soybean Height}

Weed-free treatments consistently had the tallest soybeans. Soybean height was not affected by defoliation in 
TABle 3. Targeted and actual defoliation levels of soybean for Lincoln and Concord in 2003 and 2004. Actual defoliation level indicates the leaf area lost by the late V3 stage.

\begin{tabular}{lccc}
\hline Location & Year & $\begin{array}{c}\text { Targeted } \\
\text { defoliation } \\
\text { level }\end{array}$ & $\begin{array}{c}\text { Actual } \\
\text { defoliation } \\
\text { level }\end{array}$ \\
\cline { 3 - 4 } Lincoln & 2003 & Undefoliated & 0.0 \\
& & 30 & 24 \\
& 2004 & 60 & 51 \\
& & Undefoliated & 0.0 \\
Concord & 3003 & 60 & 34 \\
& & Undefoliated & 64 \\
& & 30 & 0.0 \\
& 2004 & 60 & 31 \\
& & Undefoliated & 0.0 \\
& & 30 & 45 \\
& & 60 & 70 \\
\hline
\end{tabular}

weed-free plots (Figure 1). For example, maximum height of undefoliated soybean was $61.2 \mathrm{~cm}$ compared to $57.7 \mathrm{~cm}$ in $60 \%$ defoliation at Concord in 2003. In undefoliated weedy plots soybean height was the same as undefoliated weed-free plots at Concord in 2003. Weed interference also had no effect on height in undefoliated plots at Lincoln in 2004 (data not shown). However, soybean height was reduced by defoliation under weedy conditions. The $60 \%$ defoliation treatment reduced maximum soybean height 16
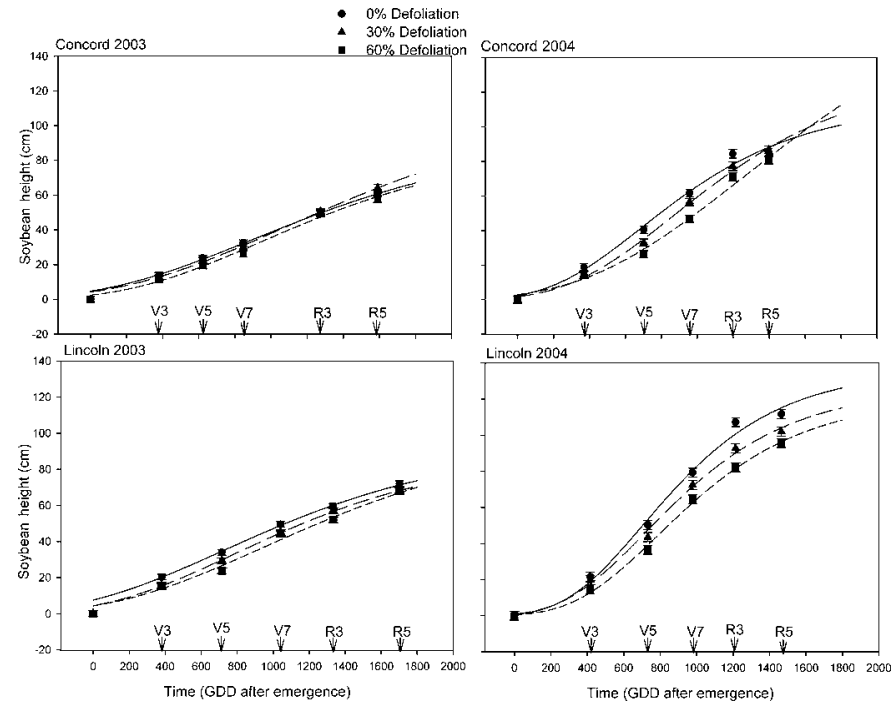

FIgURE 1. Soybean height in centimeters (Equation 1) in weed-free plots as a function of growing degree days (GDD) after crop emergence. Each line represents the model fitted to the data for undefoliated (solid line), 30\% (long dashed line), and 60\% (short dashed line) defoliated soybeans. Symbols represent treatment means, and black arrows represent mean crop growth stage. The equations of fitted regression lines are Concord 2003 undefoliated: $H=93.4 \exp (-3.0 \exp (-0.001 T)) \quad 30 \%: \quad H=113.9 \exp (-3.3$ $\exp (-0.001 T))$ 60\%: $H=89.1 \exp (-3.6 \exp (-0.001 T))$; Concord 2004 undefoliated: $H=113.2 \exp (-3.9 \exp (-0.002 T)) \quad 30 \%: H=131.7$ $\exp (-4.4 \exp (-0.002 T)) 60 \%: H=191.8 \exp (-4.2 \exp (-0.001 T))$; Lincoln 2003 undefoliated: $H=94.4 \exp (-2.5 \exp (-0.001 T)) 30 \%: H=$ $89.7 \exp (-3.0 \exp (-0.001 T))$ 60\%: $H=99.9 \exp (-3.2 \exp (-0.001 T))$; Lincoln 2004 undefoliated: $H=136.2 \exp (-5.2 \exp (-0.002 T)) 30 \%: H$ $=126.4 \exp (-4.9 \exp (-0.002 T)) \quad 60 \%: \quad H=121.0 \exp (-5.6$ $\exp (-0.002 T))$
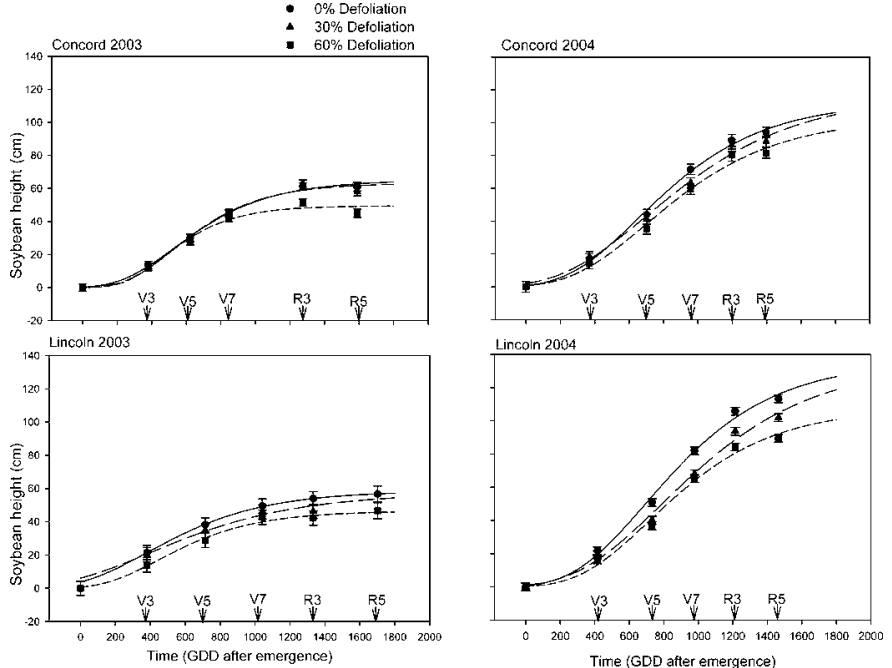

Figure 2. Soybean height in centimeters (Equation 1) in weedy plots as a function of growing degree days (GDD) after crop emergence. Each line represents the model fitted to the data for undefoliated (solid line), $30 \%$ (long dashed line), and 60\% (short dashed line) defoliated soybeans. Symbols represent treatment means and black arrows represent mean crop growth stage. The equations of fitted regression lines are: Concord 2003 undefoliated: $H=65 \exp (-5.5 \exp (-0.003 T)) 30 \%: H=63.2 \exp (-6.6$ $\exp (-0.004 T)) 60 \%: H=49.6 \exp (-7.7 \exp (-0.004 T))$; Concord 2004 undefoliated: $H=112.7 \exp (-4.9 \exp (-0.002 T)) 30 \%: H=117$ $\exp (-4.0 \exp (-0.002 T))$ 60\%: $\quad H=103.1 \exp (-4.9 \exp (-0.002 T)) ;$ Lincoln 2003 undefoliated: $H=59.8 \exp (-2.6 \exp (-0.002 T)) 30 \%: H=$ $58.3 \exp (-2.2 \exp (-0.002 T)) 60 \%: H=47.7 \exp (-3.9 \exp (-0.003 T))$; Lincoln 2004 undefoliated: $H=136.1 \exp (-5.2 \exp (-0.002 T)) 30 \%: H$ $=135.1 \exp (-4.9 \exp (-0.002 T)) \quad 60 \%: \quad H=108.0 \exp (-5.8$ $\exp (-0.002 T))$

$\mathrm{cm}$ in weedy plots at both locations in at Concord in 2003 (Figure 2). Our findings of soybean heights under weed-free conditions are similar to the results of Hammond (1989) who reported no correlation between early-season defoliation and maximum soybean height.

\section{Leaf-Area Index}

In general, LAI of soybean measured at R3 stage was affected by weed presence, but not by early-season defoliation. In addition, an increase in defoliation level combined with weed interference prolonged the time needed to achieve the critical LAI of 3.5 needed for optimum soybean growth and yield (Board et al. 1997; Shibles and Weber 1965).

Greatest LAI of soybean was measured in undefoliated weed-free plots (Figure 3), which was to be expected. Overall, defoliation levels in weed-free plots did not affect LAI in three out of four data sets, suggesting that weed-free soybean was able to recover from defoliation by the R3 stage regardless of the initial defoliation levels tested.

Lowest soybean LAI resulted from the joint effects of defoliation and weed interference. That was the case at all locations except Concord in 2003 (Figure 3). For example, season-long weedy soybean plots at Lincoln in 2003 had LAI of $1.9,1.0$, and 0.8 for undefoliated, $30 \%$, and $60 \%$ defoliated soybean, respectively. This indicated that weed interference reduced recovery of soybean leaf area from early-season insect defoliation.

Others reported that a soybean LAI of 3.5 was the critical LAI needed for $90 \%$ light interception, and for achieving the best rate of dry matter accumulation (Shibles and Weber 

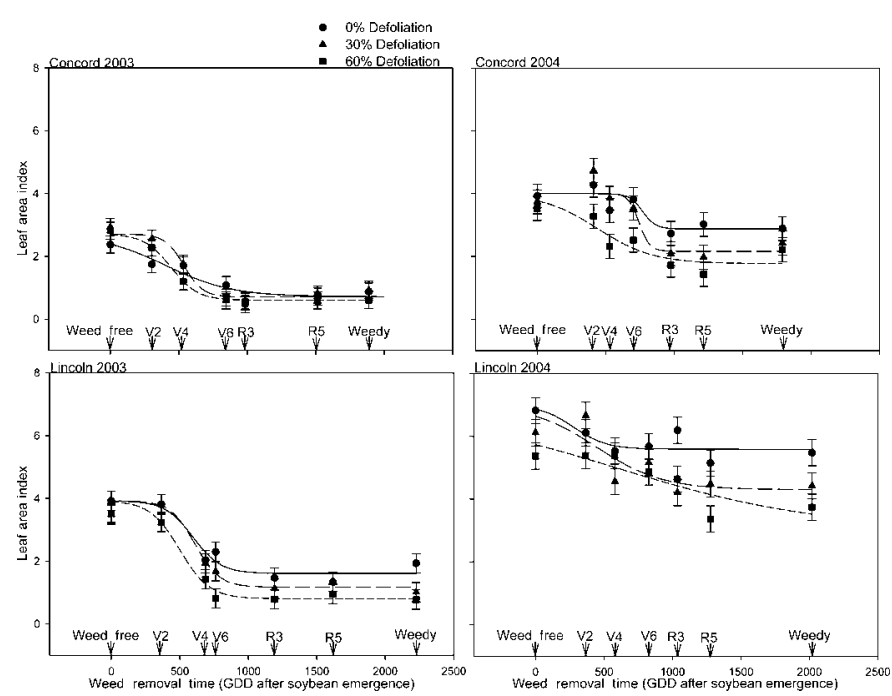

FIGURE 3. Soybean leaf-area index at R3 stage as a function of duration of weed interference in three defoliation levels: undefoliated (solid line), $30 \%$ (long dashed line), and 60\% (short dashed line) for Lincoln and Concord in 2003 and 2004. Symbols represent treatment means and lines represent the model fitted to the data.

1965) and maximum crop yield (Board et al. 1997). A soybean crop that reaches this critical LAI earlier in the season is expected to accumulate more biomass and provide greater yield. In our study, the highest LAI of season-long weedy soybeans was at Lincoln in 2004 (Figure 3). It was likely a result of lower weed density (Table 2). Therefore, lower weed competition present at that location may have allowed the soybeans to recover leaf area, and reach LAI that was above the critical LAI of 3.5. In contrast, soybean grown in season-long weedy plots at other locations/years did not achieve the critical LAI because of higher weed densities (Table 2), suggesting the negative impact of weed presence. In addition, an increase in defoliation level combined with weed interference prolonged the time needed to achieve the critical LAI of 3.5. The LAI of 3.5 in season-long weedy plots at Lincoln in 2004 occurred 48 GDD (2 d), 127 GDD (5 d), and 408 GDD (18 d) later in the undefoliated, 30 , and $60 \%$ defoliated soybean compared to weed-free soybean, respectively (data not shown). These results are similar to those of others, who reported that the time required for soybean to reach the LAI of 3.5 was increased by defoliation (Board and Harville 1992, Higley 1992, Hunt et al. 1994, Westgate 1999). These data suggest that the combined effects of defoliation and weed interference reduced soybean ability to produce critical leaf area needed for sufficient light interception and final crop yield.

\section{Biomass Production and Partitioning}

In general, TDM of soybean measured at the R5 stage was affected by weed presence but not by early-season defoliation. Soybean TDM in weed-free plots was not affected by defoliation levels at all locations except at Lincoln in 2004 (Table 4). This indicates that weed-free soybean was able to compensate for the early-season leaf removal regardless of defoliation levels, which was similar to the LAI measurements (Figure 3). However, weed presence significantly affected biomass production. Season-long weed interference caused as much as five-fold reduction in biomass compared
TABLE 4. Soybean total biomass at R5 stage (beginning seed fill) for season-long weed-free and weedy treatments.

\begin{tabular}{lcccc}
\hline & & Defoliation & \multicolumn{2}{c}{ Total biomass $^{\mathrm{a}}$} \\
\cline { 3 - 5 } Location & Year & level & Weed-free & Weedy \\
\cline { 3 - 5 } Lincoln & \multirow{3}{*}{2003} & Undefoliated & $7.4 \mathrm{a}$ & $2.7 \mathrm{a}$ \\
& & 30 & $8.7 \mathrm{a}$ & $1.8 \mathrm{a}$ \\
& & 60 & $9.0 \mathrm{a}$ & $1.1 \mathrm{a}$ \\
& \multirow{2}{*}{2004} & Undefoliated & $18.3 \mathrm{a}$ & $13.6 \mathrm{a}$ \\
& & 30 & $13.9 \mathrm{~b}$ & $12.2 \mathrm{ab}$ \\
Concord & & 60 & $15.3 \mathrm{ab}$ & $9.6 \mathrm{~b}$ \\
& \multirow{2}{*}{2003} & Undefoliated & $17.0 \mathrm{a}$ & $2.4 \mathrm{a}$ \\
& & 30 & $13.6 \mathrm{a}$ & $3.3 \mathrm{a}$ \\
& \multirow{2}{*}{2004} & 60 & $12.2 \mathrm{a}$ & $2.0 \mathrm{a}$ \\
& & Undefoliated & $16.9 \mathrm{a}$ & $10.8 \mathrm{a}$ \\
& & 30 & $17.8 \mathrm{a}$ & $8.4 \mathrm{a}$ \\
& & 60 & $15.1 \mathrm{a}$ & $7.4 \mathrm{a}$ \\
\hline
\end{tabular}

${ }^{a}$ Different letters next to total biomass values indicate differences between defoliation levels within each location and year $(n=3)(\mathrm{P}<0.05)$.

to the weed-free treatments (Table 4). For example, at Concord in 2003, the weed-free plots had 17, 13.6, and $12.2 \mathrm{~g}$ of TDM per plant compared to weedy plots with 2.4, 3.3, and $2.0 \mathrm{~g}$ of TDM in undefoliated, $30 \%$, and $60 \%$ defoliation, respectively (Table 4).

Biomass partitioning during vegetative growth was affected by both defoliation levels and weed interference. Defoliation of weed-free soybean caused an increase in new biomass partitioning to the leaves compared to the stem at all locations and years, though the increase was not statistically different in some cases (Table 5). For example, significant difference in biomass partitioning to leaves existed between undefoliated and $60 \%$ defoliated soybean at both locations in 2004, but not in 2003. This could be a mechanism by which weed-free soybean compensated for the lost leaf area, which also provided evidence for the lack of differences in the maximum LAI among defoliation levels (Figure 3). However, in weedy plots there was less biomass partitioned to the leaf compared to the stem. This was especially apparent in Lincoln, where soybeans were taller. For example, at Lincoln in 2003, 71\% of new biomass was partitioned to the stem of undefoliated weedy soybean compared to $57 \%$ in weed-free plots. Similarly, the $60 \%$ defoliated weedy soybean at the same site had $61 \%$ of new biomass partitioned to the stem compared to $48 \%$ in weed-free plots (Table 5).

During reproductive growth stages, defoliation generally decreased biomass partitioning to reproductive components in weed-free soybean (Table 6). However, when weeds were present, more biomass was partitioned to reproductive parts. At Lincoln in 2003 about $57 \%$ of new biomass was allocated to reproductive parts in undefoliated weed-free soybean, compared to $91 \%$ in weedy plots. Generally, with the reduction in $\mathrm{PC}_{\text {rep }}$ there was an increase in biomass partitioning to leaf components.

Overall, increase in biomass partitioning to the leaf during vegetative growth in weed-free plots could be a mechanism by which soybean compensated for early-season insect defoliation. These findings are similar to those of Evans et al. (2003), who reported an increase in $\mathrm{PC}_{\text {leaf }}$ in weed-free compared to weedy corn. 
TABLE 5. The fraction of new biomass partitioned to the soybean leaf $\left(\mathrm{PC}_{\text {leaf }}\right)$ and stem $\left(\mathrm{PC}_{\text {stem }}\right)$ during vegetative growth at Lincoln and Concord in 2003 and 2004.

\begin{tabular}{|c|c|c|c|c|c|}
\hline Location & Year & Weed interference & Defoliation level & $\mathrm{PC}_{\text {leaf }}$ & $\mathrm{PC}_{\text {stem }}$ \\
\hline \multirow[t]{12}{*}{ Lincoln } & 2003 & Weed-free & Undefoliated & $0.43 \mathrm{a}^{*}$ & $0.57 \mathrm{a}^{*}$ \\
\hline & & & $30 \%$ & $0.48 \mathrm{a}^{*}$ & $0.52 \mathrm{a}^{*}$ \\
\hline & & & $60 \%$ & $0.52 \mathrm{a}^{*}$ & $0.48 a^{*}$ \\
\hline & & Weedy & Undefoliated & $0.29 \mathrm{a}^{*}$ & $0.71 \mathrm{a}^{*}$ \\
\hline & & & $30 \%$ & $0.34 \mathrm{ab}^{*}$ & $0.66 \mathrm{ab}^{*}$ \\
\hline & & & $60 \%$ & $0.39 \mathrm{~b}^{*}$ & $0.61 b^{*}$ \\
\hline & 2004 & Weed-free & Undefoliated & $0.39 \mathrm{a}$ & $0.61 \mathrm{a}$ \\
\hline & & & $30 \%$ & $0.36 \mathrm{a}^{*}$ & $0.64 \mathrm{a}^{*}$ \\
\hline & & & $60 \%$ & $0.48 \mathrm{~b}^{*}$ & $0.52 \mathrm{~b}^{*}$ \\
\hline & & Weedy & Undefoliated & $0.39 \mathrm{a}$ & $0.61 \mathrm{a}$ \\
\hline & & & $30 \%$ & $0.42 \mathrm{a}^{*}$ & $0.58 a^{*}$ \\
\hline & & & $60 \%$ & $0.41 \mathrm{a}^{*}$ & $0.59 \mathrm{a}^{*}$ \\
\hline \multirow[t]{12}{*}{ Concord } & 2003 & Weed-free & Undefoliated & $0.53 \mathrm{a}^{*}$ & $0.47 \mathrm{a}^{*}$ \\
\hline & & & $30 \%$ & $0.56 \mathrm{a}$ & $0.44 \mathrm{a}$ \\
\hline & & & $60 \%$ & $0.59 \mathrm{a}^{*}$ & $0.41 \mathrm{a}^{*}$ \\
\hline & & Weedy & Undefoliated & $0.60 \mathrm{a}^{*}$ & $0.40 \mathrm{a}^{*}$ \\
\hline & & & $30 \%$ & $0.57 \mathrm{a}$ & $0.43 \mathrm{a}$ \\
\hline & & & $60 \%$ & $0.68 \mathrm{~b}^{*}$ & $0.32 \mathrm{~b}^{*}$ \\
\hline & 2004 & Weed-free & Undefoliated & $0.45 a^{*}$ & $0.55 a^{*}$ \\
\hline & & & $30 \%$ & $0.48 \mathrm{a}$ & $0.52 \mathrm{a}$ \\
\hline & & & $60 \%$ & $0.52 \mathrm{~b}^{*}$ & $0.48 b^{*}$ \\
\hline & & Weedy & Undefoliated & $0.41 \mathrm{a}^{*}$ & $0.59 a^{*}$ \\
\hline & & & $30 \%$ & $0.45 \mathrm{~b}$ & $0.55 \mathrm{~b}$ \\
\hline & & & $60 \%$ & $0.48 b^{*}$ & $0.52 \mathrm{~b}^{*}$ \\
\hline
\end{tabular}

Note. Different letters following the coefficient indicate differences at the .10 level based on a $t$ test among defoliation levels for each location, year, and duration of weed interference.

* Indicates differences $(\mathrm{P}<0.10)$ between durations of weed interference within a defoliation level for each location and year.

TABLE 6. The fraction of new biomass partitioned to the leaf $\left(\mathrm{PC}_{\text {leaf }}\right)$, stem $\left(\mathrm{PC}_{\text {stem }}\right)$, and reproductive components $(\mathrm{PC}$ rep $)$ of soybean during reproductive growth stages.

\begin{tabular}{|c|c|c|c|c|c|c|}
\hline Location & Year & Weed interference & Defoliation level & $\mathrm{PC}_{\text {leaf }}$ & $\mathrm{PC}_{\text {stem }}$ & $\mathrm{PC}_{\text {rep }}$ \\
\hline \multirow[t]{12}{*}{ Lincoln } & \multirow[t]{6}{*}{2003} & \multirow[t]{3}{*}{ Weed-free } & Undefoliated & $0.10 \mathrm{a}$ & $0.33 \mathrm{a}$ & $0.57 \mathrm{a}^{*}$ \\
\hline & & & $30 \%$ & $0.17 \mathrm{a}$ & $0.39 \mathrm{a}$ & $0.44 \mathrm{a}$ \\
\hline & & & $60 \%$ & $0.17 \mathrm{a}$ & $0.40 \mathrm{a}$ & $0.43 \mathrm{a}$ \\
\hline & & \multirow[t]{3}{*}{ Weedy } & Undefoliated & $0.00 \mathrm{a}$ & $0.09 \mathrm{a}$ & $0.91 \mathrm{a}^{*}$ \\
\hline & & & $30 \%$ & $0.05 \mathrm{a}$ & $0.23 \mathrm{a}$ & $0.72 \mathrm{ab}$ \\
\hline & & & $60 \%$ & $0.04 \mathrm{a}$ & $0.43 \mathrm{~b}$ & $0.53 \mathrm{~b}$ \\
\hline & \multirow[t]{6}{*}{2004} & \multirow[t]{3}{*}{ Weed-free } & Undefoliated & $0.23 \mathrm{a}$ & $0.53 \mathrm{a}$ & $0.24 \mathrm{a}$ \\
\hline & & & $30 \%$ & $0.25 \mathrm{a}$ & $0.52 \mathrm{a}$ & $0.23 \mathrm{a}$ \\
\hline & & & $60 \%$ & $0.25 \mathrm{a}$ & $0.54 \mathrm{a}^{*}$ & $0.21 \mathrm{a}$ \\
\hline & & \multirow[t]{3}{*}{ Weedy } & Undefoliated & $0.17 \mathrm{a}$ & $0.55 \mathrm{a}$ & $0.28 \mathrm{a}$ \\
\hline & & & $30 \%$ & $0.23 \mathrm{ab}$ & $0.53 \mathrm{a}$ & $0.24 \mathrm{a}$ \\
\hline & & & $60 \%$ & $0.28 \mathrm{~b}$ & $0.48 \mathrm{a}^{*}$ & $0.24 \mathrm{a}$ \\
\hline \multirow[t]{12}{*}{ Concord } & \multirow[t]{6}{*}{2003} & \multirow[t]{3}{*}{ Weed-free } & Undefoliated & $0.26 \mathrm{a}$ & $0.39 \mathrm{a}$ & $0.35 \mathrm{a}$ \\
\hline & & & $30 \%$ & $0.32 \mathrm{a}$ & $0.37 \mathrm{a}$ & $0.31 \mathrm{a}$ \\
\hline & & & $60 \%$ & $0.29 \mathrm{a}^{*}$ & $0.46 \mathrm{a}$ & $0.25 \mathrm{a}^{*}$ \\
\hline & & \multirow[t]{3}{*}{ Weedy } & Undefoliated & $0.39 \mathrm{a}$ & $0.29 \mathrm{a}$ & $0.32 \mathrm{a}$ \\
\hline & & & $30 \%$ & $0.28 \mathrm{a}$ & $0.22 \mathrm{a}$ & $0.5 \mathrm{ab}$ \\
\hline & & & $60 \%$ & $0 \mathrm{~b}^{*}$ & $0.25 \mathrm{a}$ & $0.75 b^{*}$ \\
\hline & \multirow[t]{6}{*}{2004} & \multirow[t]{3}{*}{ Weed-free } & Undefoliated & $0.12 \mathrm{a}$ & $0.19 \mathrm{a}$ & $0.69 \mathrm{a}$ \\
\hline & & & $30 \%$ & $0.23 \mathrm{~b}$ & $0.29 \mathrm{a}$ & $0.48 \mathrm{~b}$ \\
\hline & & & $60 \%$ & $0.23 \mathrm{~b}$ & $0.23 \mathrm{a}$ & $0.54 \mathrm{~b}$ \\
\hline & & \multirow[t]{3}{*}{ Weedy } & Undefoliated & $0.13 \mathrm{a}$ & $0.21 \mathrm{a}$ & $0.66 \mathrm{a}$ \\
\hline & & & $30 \%$ & $0.21 \mathrm{a}$ & $0.21 \mathrm{a}$ & $0.58 \mathrm{a}$ \\
\hline & & & $60 \%$ & $0.15 \mathrm{a}$ & $0.14 \mathrm{a}$ & $0.71 \mathrm{a}$ \\
\hline
\end{tabular}

Note. Different letters following the coefficient indicate differences at the .10 level based on a $t$ test among defoliation levels for each location, year, and duration of weed interference.

* Indicates differences $(\mathrm{P}<0.10)$ between durations of weed interference within a defoliation level for each location and year. 


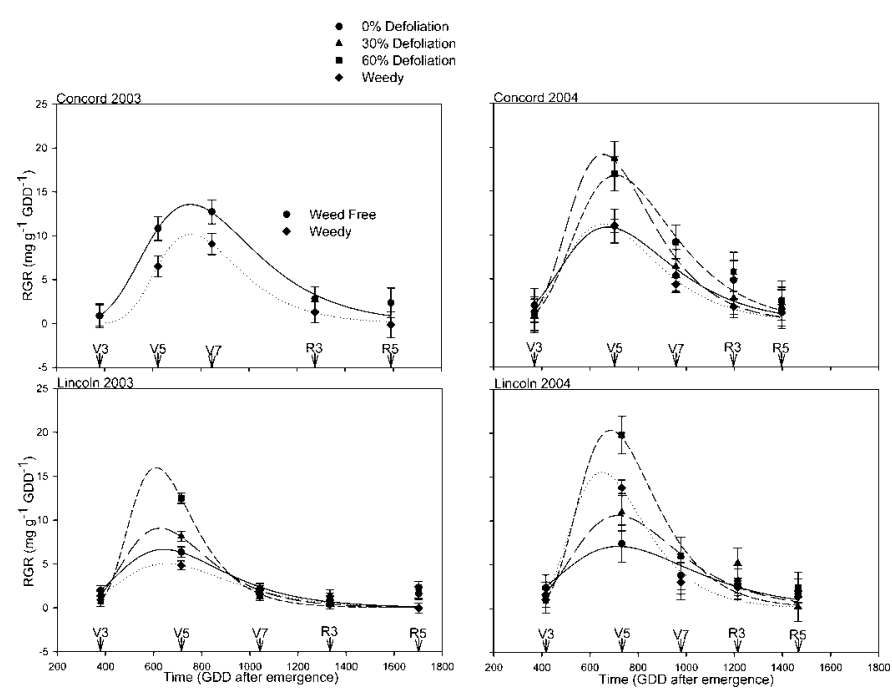

FIGURE 4. Relative growth rates of soybean as a function of time (growing degree days (GDD) after crop emergence) for Lincoln and Concord in 2003 and 2004. Regression curves (Equation 3) were constructed for weed-free soybean at each defoliation level: undefoliated (solid line), 30\% (long dashed line), and $60 \%$ (short dashed line). All data for weedy treatments was combined because there were no defoliation effects. Symbols represent treatment means, and lines represent the model fitted to the data.

\section{Relative Growth Rate}

The relative growth rate is an indicator of biomass production efficiency (Evans et al. 2003). In our study, soybean RGR was the greatest in defoliated soybeans during early stages of growth in both weed-free and weedy treatments (Figure 4). The sharp increase in RGR and biomass production by the V5 stage indicated that the crop was able to adjust its physiology as an immediate crop response to the loss of leaf area that occurred at the V1-V3 stages.

There were no effects of defoliation on RGR of soybean in the season-long weedy treatment. Therefore, the data were combined across defoliation levels and presented in a single curve for each site (Figure 4). This similarity of RGR between defoliation levels in weedy plots suggests the effects on RGR from weed interference confounded the effects from defoliation.
Overall, RGR data presented in Figure 4, suggested that new biomass production was most efficient at the V5 stage regardless of defoliation level or weed interference. This could be a mechanism for compensating for the loss of leaf area, especially because most biomass was partitioned to leaves in defoliated soybean (Table 5). Our results are similar to those of Kene and Charjan (1999), who reported that there was an increase in RGR soon after late-season defoliation occurred. Therefore, based on the results from this study with early-season defoliation, and those of Kene and Charjan (1999) with late-season defoliation, it is logical to hypothesize that the soybean crop can adjust its physiology and increase RGR when weeds are not present, which may be a mechanism by which the crop can compensate for the loss of leaf area, regardless of the timing of defoliation.

\section{Final Yield}

In general, both defoliation and weed interference reduced crop yields (Table 7). For instance, an increase in defoliation from 30 to $60 \%$ resulted in yield loss ranging from 3 to $22 \%$ under weed-free conditions compared to 30 to $97 \%$ yield reduction in season-long weedy plots depending on the year/location (Table 7).

The largest yield losses were observed in season-long weedy plots under higher defoliation levels (Table 7). For example, weed interference alone reduced yield by $50 \%$ for undefoliated soybean compared to $79 \%$ at the $60 \%$ defoliation level at Concord in 2004 (Table 7); this was the only site/year in which yield differences were observed. Yield losses from season-long weed interference at both locations in 2003 were in excess of $95 \%$, regardless of defoliation level, indicating that weed interference was the larger contributor to yield reduction than the defoliation levels tested.

In this study, an attempt was made to improve the understanding of how several basic growth parameters of soybean were affected by defoliation and weed interference. Data presented indicate that the combination of defoliation and weed interference had the most negative effects on a variety of soybean growth parameters, resulting in a crop that was less competitive against weeds.

From a practical standpoint this study suggests the need

TABLE 7. Soybean yield in season-long weedy and weed-free treatments.

\begin{tabular}{|c|c|c|c|c|c|c|}
\hline \multirow[b]{2}{*}{ Location } & \multirow[b]{2}{*}{ Year } & \multirow[b]{2}{*}{ Defoliation level } & \multicolumn{2}{|c|}{ Weed free ${ }^{a}$} & \multicolumn{2}{|c|}{ Weedy $^{\mathrm{b}}$} \\
\hline & & & $\mathrm{kg} \mathrm{ha}^{-1}$ & $\%$ yield loss & $\mathrm{kg} \mathrm{ha}^{-1}$ & $\%$ yield loss \\
\hline \multirow[t]{6}{*}{ Lincoln } & 2003 & Undefoliated & 2,131 & $0 \mathrm{a}$ & 94 & $96 \mathrm{a}$ \\
\hline & & $30 \%$ & 2,062 & $3 a$ & 77 & $96 a$ \\
\hline & & $60 \%$ & 1,926 & $10 \mathrm{~b}$ & 56 & $97 a$ \\
\hline & 2004 & Undefoliated & 3,538 & $0 \mathrm{a}$ & 3,013 & $15 \mathrm{a}$ \\
\hline & & $30 \%$ & 3,402 & $4 \mathrm{a}$ & 2,467 & $30 \mathrm{a}$ \\
\hline & & $60 \%$ & 2,751 & $22 \mathrm{~b}$ & 2,530 & $29 a$ \\
\hline \multirow[t]{6}{*}{ Concord } & 2003 & Undefoliated & 2,024 & $0 \mathrm{a}$ & 59 & $97 \mathrm{a}$ \\
\hline & & $30 \%$ & 1,895 & $6 a$ & 82 & $96 a$ \\
\hline & & $60 \%$ & 1,859 & $8 \mathrm{a}$ & 57 & $97 \mathrm{a}$ \\
\hline & 2004 & Undefoliated & 2,817 & $0 \mathrm{a}$ & 1,412 & $50 \mathrm{a}$ \\
\hline & & $30 \%$ & 2,433 & $14 \mathrm{a}$ & 871 & $69 \mathrm{ab}$ \\
\hline & & $60 \%$ & 2,216 & $21 \mathrm{~b}$ & 602 & $79 \mathrm{~b}$ \\
\hline
\end{tabular}

Note. Different letters in \% yield loss column indicate differences $(\mathrm{P}<0.05)$ between defoliation levels for each location and year.

${ }^{a}$ Indicates percentage yield loss relative to the undefoliated soybean without weed interference.

b Indicates percentage yield loss relative to the undefoliated weed-free soybean with weed interference. 
for monitoring early-season insect density and weed growth in order to design appropriate pest management practices to protect the crop. For example, early-season control of insects can enhance crop tolerance to weed presence and vice versa. If control of either pest is delayed, simultaneous control of both pests may be required. Stern et al. (1959) presented an IPM concept in which practitioners recognize the agroecosystem as a unified system where insects, diseases, plant nutrition, and other factors simultaneously impact crop growth and final yield. Data are presented in this article in an attempt to capture the interactions between early-season defoliators and weed interference.

\section{Sources of Materials}

${ }^{1}$ Roundup Weathermax, Monsanto Company, 800 North Lindbergh Boulevard, St. Louis, MO 63167.

${ }^{2}$ LI-3100, LI-COR, Inc., 4421 Superior Street, Lincoln, NE 68504

3 SAS version 8.0, Statistical Analysis Systems Institute, SAS Campus Drive, Cary, NC 27512

\section{Acknowledgments}

Published as University of Nebraska Agricultural Research Division Journal Series No. 14538. Thanks are extended to the Nebraska Soybean Board for providing funding for this research project. Also, special gratitude is due to Jerry Echtenkamp, Jon Scott, Ray Brentlinger, Doug Miller, Kevin Horky, Shawn Hock, and numerous summer workers for assisting in plot maintenance and data collection.

\section{Literature Cited}

Anonymous. 2004. Historical Track Records. Washington, D.C.: National Agricultural Statistics Service, U.S. Department of Agriculture. 215 p.

Board, J. E. and B. G. Harville. 1992. Explanations for greater light interception in narrow- vs. wide-row soybean. Crop Sci. 32:198-202.

Board, J. E., A. T. Wier, and D. J. Boethel. 1997. Critical light interception during seed filling for insecticide application and optimum soybean grain yield. Agron. J. 89:369-374.

Evans, S. P., S. Z. Knezevic, J. L. Lindquist, and C. A. Shapiro. 2003. Influence of nitrogen and duration of weed interference on corn growth and development. Weed Sci. 51:546-556.
Fehr, W. R., and C. E. Caviness. 1977. Stages of Soybean Development. Ames: Iowa State University Cooperative Extension Service Special Rep. 80.

Hammond, R. B. 1989. Effects of leaf removal at growth V1 on yield and other growth parameters. J. Kansas Entomol. Soc. 62:96-102.

Higley, L. G. 1992. New understandings of soybean defoliation and their implication for pest management. Pages 56-65 In L. G. Copping et al., eds. Pest Management in Soybean. London: Elsevier.

Hunt, R. 1982. Plant Growth Curves: The Functional Approach to Growth Analysis. London: Edward Arnold, pp. 51-54, 128-135.

Hunt, R. 1990. Basic Growth Analysis: Plant Growth Analysis for Beginners. London: Unwin Hyman, pp. 35-72.

Hunt, T. E., L. G. Higley, and J. F. Witkowski. 1994. Soybean growth and yield after simulated bean leaf beetle injury to seedlings. Agron. J. 86: 140-146.

Hunt, T. E., L. G. Higley, and J. F. Witkowski. 1995. Bean leaf beetle injury to seedling soybean: consumption, effects of leaf expansion, and economic injury levels. Agron. J. 87:183-188.

Kene, H. K. and Y. D. Charjan. 1999. Effect of defoliation on growth and yield of soybean. PKV Res. J. 23:45-47.

Knezevic, S. Z., S. P. Evans, and M. Mainz. 2003a. Row spacing influences the critical timing for weed removal in soybean (Glycine max). Weed Technol. 17:666-673.

Knezevic, S. Z., S. P. Evans, E. E. Blankenship, R. C. Van Acker, and J. L. Lindquist. 2002. Critical period for weed control: the concept and data analysis. Weed Sci. 50:773-786.

Knezevic, S. Z., S. P. Evans, and M. Mainz. 2003b. Yield penalty due to delayed weed control in corn and soybean [on-line]. Crop Manage. doi:10.1094/CM-2003-0219-01-RS.

Littell, R. C., G. A. Milliken, W. W. Stroup, and R. D. Wolfinger. 1996. SAS ${ }^{\circledast}$ System for Mixed Models. Cary, NC: Statistical Analysis Systems Institute. 633 p.

Martin, S. G., R. C. Van Acker, and L. F. Friesen. 2001. Critical period of weed control in spring canola. Weed Sci. 49:326-333.

Shibles, R. M. and C. R. Weber. 1965. Leaf area, solar radiation interception and dry matter production by soybeans. Crop Sci. 5:575-577.

Smelser, B. R., and L. P. Pedigo. 1991. Phenology of Cerotoma trifurcata on soybean and alfalfa in central Iowa. Env. Entomol. 20:514-519.

Stern, V. M., R. F. Smith, R. van den Bosch, and K. S. Hagen. 1959. The integrated control concept. Hilgardia 29:81-101.

Talekar, N. S. and H. R. Lee. 1988. Response of soybean to foliage loss in Taiwan. J. Econ. Entomol. 81:1363-1368.

Weber, C. R. 1955. Effects of defoliation and topping simulating hail injury to soybeans. Agron. J. 47:262-266.

Weber, C. R. and B. E. Caldwell. 1966. Effects of defoliation and stem bruising on soybeans. Crop Sci. 6:25-27.

Westgate, M. E. 1999. Managing soybean for photosynthetic efficiency. Pages 223-228 in Proceedings, World Soybean Research Conference VI. August 4-7, 1999, Chicago, IL.

Received January 17, 2006, and approved March 20, 2006. 